\title{
Precocious puberty in Turner Syndrome: report of a case and review of the literature
}

\author{
Nicola Improda', Martina Rezzuto', Sara Alfano', Giancarlo Parenti', Pietro Vajro², Claudio Pignata' \\ and Mariacarolina Salerno ${ }^{1 *}$
}

\begin{abstract}
Introduction: Turner Syndrome (TS) is caused by monosomy or structural abnormalities of the X chromosome, with a prevalence of about 1/2000 females live birth. Most important clinical features of TS are short stature and gonadal failure. Approximately one third of girls with TS may undergo spontaneous puberty. Here we report on the case of a girl with a rare 45X0/47XXX mosaic TS exhibiting a precocious puberty.

Case report: The patient was diagnosed with TS at the age of 4 years, upon a diagnostic work-up for dysmorphic features. Chromosome analysis revealed a mosaic karyotype (45X0/47XXX). She presented with normal height and normal growth velocity so that Growth Hormone $(G H)$ therapy was not started. She was referred to our Department at the age of 7 years and 10 months, because of vaginal bleeding. A physical examination revealed a Tanner stage III for breast and Tanner stage III for pubic hair development. Height and weight were within the normal range for age. Psychological evaluation showed moderate global developmental delay, together with emotional and social immaturity and reading difficulties. The growth rate was accelerated. Her bone age was 10 years. Pelvic ultrasound demonstrated increased size for age of both the uterus and the ovaries, with bilateral ovarian follicles. GnRH stimulation test revealed pubertal response of gonadotropins (peak LH $22.5 \mathrm{mlU} / \mathrm{ml}$ ). MRI of the brain was normal. These clinical, radiologic and laboratory findings were consistent with a diagnosis of idiopathic central precocious puberty; therefore, GnRH analog therapy was started, in order to slow pubertal progression and to preserve adult stature. Furthermore, GH treatment was added to further improve adult height.

Conclusion: Our case highlights the possibility of precocious puberty as an atypical clinical feature of TS. Thus, precocious puberty may occur in TS girls when a dosage compensation by the cell line with more than two $X$ chromosomes allows normal ovarian function. GnRH analog therapy in addition to GH treatment should be recommended in TS girls with precocious puberty in order to slow pubertal progression and to preserve adult stature.
\end{abstract}

Keywords: Turner syndrome, Precocious puberty, GnRH analog therapy

\section{Background}

Turner syndrome (TS) is a relatively common chromosomal disorder caused by complete or partial X monosomy, with a prevalence of approximately $1 / 2000$ females live births [1]. The genetic background of TS is highly variable. The most frequent occurring karyotypes are $45, \mathrm{X}$, karyotypes with an isochromosome of $\mathrm{X}(\mathrm{i}(\mathrm{Xq})$ or $\mathrm{i}(\mathrm{Xp}))$, the mosaic karyotype of $45, \mathrm{X} / 46 \mathrm{XX}$,

\footnotetext{
* Correspondence: salerno@unina.it

'Department of Pediatrics, Federico II University of Naples, Naples, Italy

Full list of author information is available at the end of the article
}

and karyotypes containing an entire $\mathrm{Y}$ chromosome or parts thereof [2]. The mosaic TS karyotype occurs in approximately $30 \%$ of all patients with TS [3]. Short stature, gonadal dysgenesis and congenital malformations are the main clinical features, although a number of others signs and symptoms are seen more frequently with the syndrome [1]. Although in TS there is not a clear genotype/phenotype correlation, girls with mosaic TS who have a normal cell line, or an extra $\mathrm{X}$ chromosome tend to exhibit milder phenotypes [3].

Absent pubertal development and primary amenorrhea occurs in most individuals with TS, due to accelerated loss

\section{Biomed Central}

(c) 2012 Improda et al.; licensee BioMed Central Ltd. This is an Open Access article distributed under the terms of the Creative Commons Attribution License (http://creativecommons.org/licenses/by/2.0), which permits unrestricted use, distribution, and reproduction in any medium, provided the original work is properly cited. 
of oocytes in the 45, $\mathrm{X}$ ovary, leaving few follicles in a fibrous strike by birth. Approximately one third of girls with TS undergo spontaneous puberty, but only half of those complete puberty with menarche. Spontaneous pregnancies are rare (2-5\%) [4]. A few rare cases of precocious puberty have been described, mainly in girls with mosaic TS (45X0/46XX or X structural abnormalities) [5-8].

We report on the first case of precocious puberty in a 45X0/47XXX mosaic TS.

\section{Case report}

A female child was born pre-term (32 weeks of gestation) with a birth weight of $2.900 \mathrm{~kg}$ and a length of 49 $\mathrm{cm}$. Postnatal period was uneventful. She was diagnosed with TS at the age of 4 years, upon a diagnostic work-up for dysmorphic features. High resolution chromosome analysis revealed a mosaic karyotype (55\% 45X0/45\% 47XXX); FISH analysis excluded Y-chromosome-specific sequences. Her stature was normal and within the target height, no other associated abnormalities were detected, thus she was followed by the general pediatrician.

She was referred to our Department at the age of 7 years and 10 months, because of vaginal bleeding. A physical examination revealed a Tanner stage III for breast development, Tanner stage III for pubic hair development, axillary hair and scoliosis. Height and weight were within the normal range for age (height $126 \mathrm{~cm}$, 25 th percentile, and weight $26 \mathrm{~kg}$, 25-50th percentile, respectively). The growth rate was accelerated $(12 \mathrm{~cm} /$ year) (Figure 1). Psychological evaluation showed moderate global developmental delay, together with emotional and social immaturity and reading difficulties. Skeletal maturation, evaluated by a left wrist $\mathrm{x}$-ray was 10 years. Pelvic ultrasound demonstrated increased size for age of both the uterus (longitudinal diameter $53 \mathrm{~mm}$ ) and the ovaries (right ovary volume $3 \mathrm{ml}$ and left $3.3 \mathrm{ml}$ ) with bilateral ovarian follicles. Abdominal and cardiac ultrasound, as well as routine hematological and biochemical analysis were normal. Endocrine evaluation revealed FSH levels $7.66 \mathrm{mIU} / \mathrm{mL}$, LH levels $1.68 \mathrm{mIU} / \mathrm{mL}$, and slightly elevated estradiol levels $(28.2 \mathrm{pg} / \mathrm{mL})$. GnRH stimulation test revealed pubertal response of gonadotropins with $\mathrm{LH}$ peak value of $22.5 \mathrm{mIU} / \mathrm{ml}$ and $\mathrm{FSH}$ peak value of $17.8 \mathrm{mIU} / \mathrm{mL}$. Furthermore, assessment of thyroid function showed thyroid stimulating hormone (TSH) $5.5 \mu \mathrm{IU} / \mathrm{mL}$ (normal range: $0.3-4.2 \mu \mathrm{IU} / \mathrm{mL}$ ), with normal levels of free $\mathrm{T} 4(1.25 \mathrm{ng} / \mathrm{dl}$, normal range $0.8-1.7$ ), and positive thyroid anti-TPO autoantibodies (100 IU/l, normal value less than 35), thus suggesting a condition of mild subclinical hypothyroidism in the context of autoimmune thyroiditis [9-11]. Other autoimmune diseases were ruled out by appropriate investigations [12-15]. Serum IGF-1 level was within normal limits. MRI of the brain was normal.
These clinical, radiologic and laboratory findings were consistent with a diagnosis of idiopathic central precocious puberty; therefore, GnRH analog therapy was started, in order to slow pubertal progression and to preserve maximum adult stature $[5,16]$. Furthermore, GH treatment was added to further improve adult height.

At the chronological age of 12 years and bone age of 13 years, GnRH analog therapy was discontinued, resulting in recovery of pubertal development which was completed by menarche at the age of $12 \mathrm{yr}$ and 10 months. She is now 13 years old, she is still receiving GH treatment, her near final height is $150 \mathrm{~cm}$, slightly below the target height (Figure 1).

\section{Discussion}

We report on the first case of precocious puberty in a TS with a rare 45X0/47XXX mosaic karyotype.

TS is associated with a constellation of potential abnormalities involving many organ systems, making it a challenging disorder for health care providers and families. The genetic background of TS is highly variable. About $30 \%$ of TS girls have a mosaic chromosomal structure, with only $1 \%$ showing a $45 \mathrm{X} 0 / 47 \mathrm{XXX}$ mosaicism [17]. The correlation between genotype and phenotype is not yet well understood, but generally patients with a 45,X karyotype tend to have a more severe phenotype than those who are mosaic with a normal cell line [2].

Short stature, ovarian dysgenesis and infertility are clinical hallmarks in the majority of patients with TS. The incidence of spontaneous puberty in TS is reported to be about one third. In an Italian retrospective multicenter study, $33.5 \%$ of 522 patients older than $12 \mathrm{yr}$ with Turner syndrome presented spontaneous pubertal development, but only $16.1 \%$ completed puberty with menarche [18].

Precocious puberty in TS patients is very rare. To date, only five cases have been reported in the Literature, four of them showing mosaic TS and one a karyotype with structural abnormality of one X chromosome [5-8].

To our knowledge this is the first case of precocious puberty reported in a TS with a mosaic karyotype characterized by a cell line with $\mathrm{X}$ chromosome monosomy and a cell line with three copy of the $\mathrm{X}$ chromosome, thus suggesting a post-zygotic unbalanced disjunction of the sex chromosomes. In addition to precocious puberty, our patient showed other peculiar clinical features, such as normal height and neuro-psychological problems, likely related to the quantitative proportion of $45 \mathrm{X}$ to 47XXX cell-lines in different tissues and organs [19].

Triple X syndrome $(47 \mathrm{XXX})$ is a sex chromosome aneuploidy that occurs in approximately 1 in 1000 female births. Although non-mosaic 47,XXX karyotypes are the most frequent, mosaicism occurs in approximately $10 \%$ 


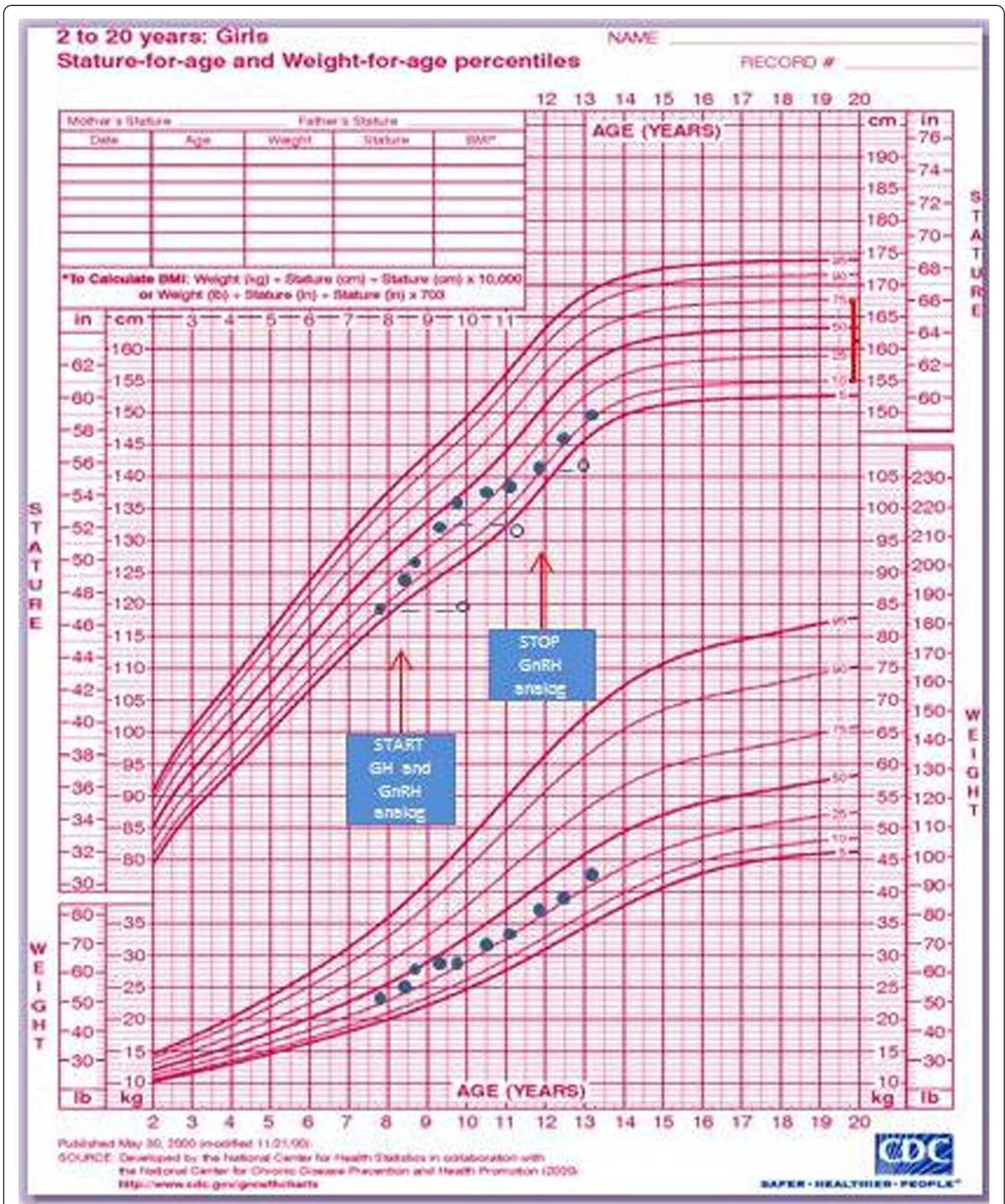

Figure 1 Growth chart of our patient. 
of cases and in many combinations such as 46XX/ 47XXX or $47 \mathrm{XXX} / 48 \mathrm{XXXX}$, or in combination including Turner syndrome cell lines such as $45 \mathrm{X} / 47 \mathrm{XXX}$ or $45 \mathrm{X} /$ 46XX/47XXX. Clinical characteristics include epicanthal folds, hypertelorism, upslanting palpebral fissures, clinodactyly, overlapping digits, pes planus and pectus excavatum. The majority of cases are asymptomatic with normal pubertal onset and sexual development [20]. However, pubertal abnormalities have been reported in Triple $\mathrm{X}$ syndrome, ranging from premature ovarian insufficiency [21] to precocious puberty [22,23].

Genes located on the proximal region of the short arm of the $\mathrm{X}$ chromosome are important for normal ovarian function and development and the haploinsufficiency of these genes is thought to be implicated in the pathogenesis of gonadal dysgenesis associated with TS [24]. On the contrary, spontaneous puberty has been reported with a significantly higher frequency among mosaic TS with cell lines having more than one X. These observations suggest a cardinal influence of the $\mathrm{X}$ chromosome on the appearance of spontaneous puberty [18]. In keeping with this, our case suggests that even precocious puberty may occur in TS girls when a dosage compensation by the cell line with more than two $\mathrm{X}$ chromosomes allows normal ovarian function.

The pathogenetic mechanism for central precocious puberty in sex chromosome aneuploidies, particularly in TS, is still unclear. Abnormalities in the hypothalamic feedback system, with increased levels of gonadotropins to compensate for blunted ovarian function, or FSH surge commonly seen in TS before the ovarian failure have been hypothesized [7]. Elevated levels of TSH have also been proposed as a mechanism in causing precocious puberty in girls with TS, due to the interaction between TSH and human FSH receptor [25]. In our patient it seems unlikely that the slightly increase in TSH levels may be responsible for precocious puberty, because TSH levels were stable over time and no other functional abnormalities were detected.

The decision to treat with $\mathrm{GnRH}$ analog a condition such as TS, generally associated with ovarian failure, is challenging. The observation that untreated precocious puberty is generally associated with impaired adult height due to bone age advancement and that short stature is per se a hallmark of TS prompted us to undertake a treatment with GnRH analog [26]. Again, despite a normal GH secretion following a pharmacological stimulation test [27], evidence indicates that a GH treatment may improve adult height in TS as well as in other syndromes $[28,29]$. For this reason, the initiation of $\mathrm{GH}$ therapy is currently considered as soon as growth failure is evidenced even though short stature is not present [4]. In our patient, $\mathrm{GH}$ therapy was not initially started due to normal height and normal growth velocity. However, after the diagnosis of precocious puberty, GH therapy was considered in order to improve adult height.

\section{Conclusion}

Our case highlights the possibility of precocious puberty as an atypical clinical feature of TS. Precocious puberty may occur in TS girls when a dosage compensation by the cell line with more than two $\mathrm{X}$ chromosomes allows normal ovarian function. GnRH analog therapy in addition to $\mathrm{GH}$ treatment should be recommended in TS girls with precocious puberty in order to slow pubertal progression and to preserve adult stature.

\section{Consent}

Written informed consent was obtained from the parents of the patient for publication of this Case report and any accompanying images. A copy of the written consent is available for review by the Editor-in-Chief of this journal.

\section{Abbreviations}

TS: Turner Syndrome; GH: Growth Hormone.

\section{Competing interests}

The authors declare that they have no competing interests.

\section{Authors' contributions}

All authors have equally participated in drafting of the manuscript and/or critical revision of the manuscript for important intellectual content. All authors read and approved the final manuscript.

\section{Author details}

${ }^{1}$ Department of Pediatrics, Federico II University of Naples, Naples, Italy. ${ }^{2}$ Chair of Pediatrics, University of Salerno, Salerno, Italy.

Received: 2 October 2012 Accepted: 15 October 2012 Published: 17 October 2012

\section{References}

1. Stochholm K, Juul S, Juel K, Naeraa RW, Gravholt CH: Prevalence, incidence, diagnostic delay and mortality in Turner Syndrome. J Clin Endocrinol Metab 2006, 91(10):3897-3902.

2. Davenport ML: Approach to the Patient with Turner Syndrome. $J$ Clin Endocrinol Metab 2010, 95(4):1487-1495

3. Donaldson MDC, Gault EJ, Tan KW, Dunger DB: Optimising management in Turner syndrome: from infancy to adult transfer. Arch Dis Child 2006, 91:513-520.

4. Bondy CA for The Turner Syndrome Consensus Study Group: Care of Girls and Women with Turner Syndrome: A Guideline of the Turner Syndrome Study Group. J Clin Endocrinol Metab 2007, 92(1):10-25.

5. Huseman CA: Mosaic Turner syndrome with precocious puberty. J Pediatr 1983, 102:892-894.

6. Evanchec KA, Rotenstein D: Treatment of precocious puberty in two patients with Turner mosaicism. J Pediatr Endocrinol Metab 2005, 18:819-822.

7. Sabin MA, Zacharin MR: Precocious puberty in Turner syndrome. J Paediatr Child Health 2007, 43:776-778.

8. Baek JU, Park HK, Shim EJ, Hwang IT: Precocious Puberty in Turner Syndrome Variant. J Pediatr Adolesc Gynecol 2012, 25:e113-e114.

9. Wasniewska M, Salerno M, Cassio A, Corrias A, Aversa T, Zirilli G, Capalbo D, Bal M, Mussa A, De Luca F: Prospective evaluation of the natural course of idiopathic subclinical hypothyroidism in childhood and adolescence. Eur J Endocrinol 2009, 160(3):417-421.

10. Radetti G, Maselli M, Buzi F, Corrias A, Mussa A, Cambiaso P, Salerno M, Cappa M, Baiocchi M, Gastaldi R, Minerba L, Loche S: The natural history of 
the normal/mild elevated TSH serum levels in children and adolescents with Hashimoto's thyroiditis and isolated hyperthyrotropinaemia: a 3-year follow-up. Clin Endocrinol (Oxf) 2012, 76(3):394-398.

11. Cerbone M, Bravaccio C, Capalbo D, Polizzi M, Wasniewska M, Cioffi D, Improda N, Valenzise M, Bruzzese D, De Luca F, Salerno M: Linear growth and intellectual outcome in children with long-term idiopathic subclinical hypothyroidism. Eur J Endocrinol 2011, 164(4):591-597.

12. Capalbo D, Fusco A, Aloj G, Improda N, Vitiello L, Dianzani U, Betterle C, Salerno M, Pignata C: High intrafamilial variability in autoimmune polyendocrinopathy-candidiasis-ectodermal dystrophy: a case study. J Endocrinol Invest 2012, 35(1):77-81.

13. Capalbo D, Mazza C, Giordano R, Improda N, Arvat E, Cervato S, Morlin L, Pignata C, Betterle C, Salerno M: Molecular background and genotypephenotype correlation in autoimmune-polyendocrinopathy-candidiasisectodermal-distrophy patients from Campania and in their relatives. J Endocrinol Invest 2012, 35(2):169-173.

14. Mazza C, Buzi F, Ortolani F, Vitali A, Notarangelo LD, Weber G, Bacchetta R, Soresina A, Lougaris V, Greggio NA, Taddio A, Pasic S, de Vroede M, Pac M, Kilic SS, Ozden S, Rusconi R, Martino S, Capalbo D, Salerno M, Pignata C, Radetti G, Maggiore G, Plebani A, Notarangelo LD, Badolato R: Clinical heterogeneity and diagnostic delay of autoimmune polyendocrinopathy-candidiasis-ectodermal dystrophy syndrome. Clin Immunol 2011, 139(1):6-11.

15. De Bellis A, Salerno M, Conte M, Coronella C, Tirelli G, Battaglia M, Esposito V, Ruocco G, Bellastella G, Bizzarro A, Bellastella A: Antipituitary antibodies recognizing growth hormone $(\mathrm{GH})$-producing cells in children with idiopathic GH deficiency and in children with idiopathic short stature. J Clin Endocrinol Metab 2006, 91(7):2484-2489.

16. Oetren-Klein K, Barnes KM, Jones JV, Feuillan PP, Cutler GB: Increased final height in precocious puberty after long-term treatment with LHRH agonists: the National Institutes of Health experience. J Clin Endocrinol Metab 2001, 86:4711-4716.

17. Abir R, Fisch B, Nahum R, Orvieto R, Nitke S, Rafael Ben Z: Turner's syndrome and fertility: current status and possible putative prospects. Hum Reprod Updat 2001, 7:603-610.

18. Pasquino AM, Passeri F, Pucarelli I, Segni M, Municchi G: Spontaneous Pubertal Development in Turner's Syndrome. J Clin Endocrinol Metab 1997, 82(6):1810-1813.

19. Tauchmanova L, Rossi R, Pulcrano M, Tarantino L, Baldi C, Lombardi G: Turner's syndrome mosaicism 45X/47XXX: an interesting natural history. $J$ Endocrinol Invest 2001, 24(10):811-815.

20. Cordts EB, Christofolini DM, Dos Santos AA, Bianco B, Barbosa CP: Genetic aspects of premature ovarian failure: a literature review. Arch Gynecol Obstet 2011, 283(3):635-643.

21. Goswami R, Goswami D, Kabra M, Gupta N, Dubey S, Dadhwal V: Prevalence of the triple $\mathrm{X}$ syndrome in phenotipically normal women with premature ovarian failure and its association with autoimmune thyroid disorders. Fertil Steril 2003, 80(4):1052-1054.

22. Grosso S, Anichini C, Berardi R, Balestri P, Pucci L, Morgese G: Central precocious puberty and abnormal chromosomal patterns. Endocr Pathol 2000, 11:69-71.

23. Valerio G, Franzese A, Palmieri A, Mackay DJ, Gardner RJ, Temple JK: Central precocious puberty in a girl with triple $\mathrm{x}$ syndrome and neonatal diabetes mellitus associated with paternal isodisomy of chromosome 6 . J Pediatr Endocrinol Metab 2001, 14(7):897-900.

24. Ranke MB, Saenger P: Turner's syndrome. Lancet 2001, 358:309-314.

25. Anasti JN, Flack MR, Froehlich J, Nelson LM, Nisula BC: A potential novel mechanism for precocious puberty in juvenile hypothyroidism. J Clin Endocrinol Metab 1995, 80(1):276-279.

26. Carel JC, Eugster EA, Rogol A, Ghizzoni L, Palmert MR: Consensus Statement on the Use of Gonadotropin-Releasing Hormone Analogs in Children. Pediatrics 2009, 123:e752.

27. Corneli G, Di Somma C, Prodam F, Bellone J, Bellone S, Gasco V, Baldelli R, Rovere S, Schneider HJ, Gargantini L, Gastaldi R, Ghizzoni L, Valle D, Salerno M, Colao A, Bona G, Ghigo E, Maghnie M, Aimaretti G: Cut-off limits of the $\mathrm{GH}$ response to GHRH plus arginine test and IGF-I levels for the diagnosis of $\mathrm{GH}$ deficiency in late adolescents and young adults. Eur J Endocrinol 2007, 157(6):701-708.

28. Saenger P, Wikland KA, Conway GS, Davenport M, Gravholt CH, Hintz R, Hovatta O, Hultcrantz M, Landin-Wilhelmsen K, Lin A, Lippe B, Pasquino AM, Ranke MB, Rosenfeld R, Silverbach M: Fifth International Symposium on
Turner Syndrome. Recommendations for the diagnosis and management of Turner Syndrome. J Clin Endocrinol Metab 2001, 86(7):3061-3069.

29. Capalbo D, Melis D, De Martino L, Palamaro L, Riccomagno S, Bona G, Cordeddu V, Pignata C, Salerno M: Noonan-like syndrome with loose anagen hair associated with growth hormone insensitivity and atypical neurological manifestations. Am J Med Genet A 2012, 158A:856-860.

doi:10.1186/1824-7288-38-54

Cite this article as: Improda et al.: Precocious puberty in Turner

Syndrome: report of a case and review of the literature. Italian Journal of Pediatrics 2012 38:54.

\section{Submit your next manuscript to BioMed Central and take full advantage of:}

- Convenient online submission

- Thorough peer review

- No space constraints or color figure charges

- Immediate publication on acceptance

- Inclusion in PubMed, CAS, Scopus and Google Scholar

- Research which is freely available for redistribution

Submit your manuscript at www.biomedcentral.com/submit
C) Biomed Central 